Серія: Педагогічні науки. - Вип.3. - Бердянськ : БДПУ, 2019. - 453 с.

УДК 373.5.091.64:51]:004

DOI 10.31494/2412-9208-2019-1-3-144-154

\title{
MATHEMATICS AND INFORMATICS INTERCONNECTIONS IN A COMPETENTLY ORIENTED CONTENT OF THE MODERN MATHEMATICAL TUTORIAL
}

\section{МІЖПРЕДМЕТНІ ЗВ'ЯЗКИ МАТЕМАТИКИ ТА IНФОРМАТИКИ В КОМПЕТЕНТНІСНО ОРІЄНТОВАНОМУ ЗМІСТІ СУЧАСНОГО ПІДРУЧНИКА МАТЕМАТИКИ}

\author{
Svetlana PANOVA, \\ Candidate of Pedagogical \\ Sciences \\ Berdiansk State Pedagogical \\ University \\ $\triangle 4$ Schmidt St.,
}

https://orcid.org/0000-0002-7734-8182

svetapanova1985@gmail.com

Berdiansk, Zaporizhzhia region, 71100

Original manuscript received: October 01, 2019

Revised manuscript accepted: December 11, 2019

\author{
Світлана ПАНОВА, \\ кандидат педагогічних наук
}


intersubject links of mathematics and computer science. As well as the development of a system of computer-oriented tasks for math for secondary school students.

Key words: mathematics textbook, competency approach, cross-curricular links, mathematical education, digital competence.

Вступ. Інформатизація сучасного суспільства передбачає нові підходи до навчання математики в закладах загальної середньої освіти, що потребують формування в учнів інформаційно-цифрової компетентності. Одним із них $є$ реалізація міжпредметного підходу у навчанні математики, що базується на інтеграції та координації знань 3 різних навчальних дисциплін, що сприяє формуванню ключових компетенностей учня.

Разом з тим, процес реформування освітньої системи України зробив актуальним низку проблем, пов'язаних зі змістом сучасного підручника. Дослідники та автори шкільних підручників обговорюють це питання на різноманітних конференціях, форумах та круглих столах всеукраїнського та міжнародного рівнів, розробляють рекомендації щодо подальших ефективних шляхів покращення ситуації. Зокрема, 21 лютого 2019 року у Львові відбувся круглий стіл "Від авторів до учнів: шлях шкільного підручника", на якому методисти обговорили проблеми, що виникли в процесі створення підручників, виокремили ряд проблем сучасного підручникотворення та висловили своє бачення щодо їх розв'язання (“Освітня політика”, 2019). Зокрема, ними було акцентовано увагу на проблемі формування змісту сучасних підручників відповідно до нових стандартів.

Над розв'язанням вищезазначеного завдвння постійно працює Інститут педагогіки НАПН України, який не тільки організовує конференції, але і випускає з 2002 року фаховий збірник наукових праць “Актуальні питання теорії підручникотворення, особливості створення сучасної навчальної і науково-методичної літератури". У ньому вже протягом декількох років публікуються статті щодо проблем формування змісту сучасних підручників математики, алгебри та геометрії на компетентнісній основі. Аналіз наукових праць дозволив виявити, що проблема розробки змісту сучасного підручника математики на компетентнісній основі привертає особливу увагу науковців.

Так, обґрунтування необхідності реалізації компетентнісного підходу в освіті, розкриття його історичних, теоретико-методологічних аспектів $€$ предметом дослідження багатьох вчених (О. Овчарук, О. Савченко, Г.Селевко, О. Часнікова та інші). Проблему компетентнісного підходу в навчанні математики висвітлено в працях А. Пруса, С. Ракова та інших. Досліджуючи питання реалізації компетентнісного підходу до вибору змісту навчання математики, М. Бурда, Д. Васильєва, О. Глобін та Н. Мацько зазначають, що якість математичної підготовки учнів відображає рівень готовності "суспільства до соціально-економічного розвитку, мобільності особистості в освоєнні і впровадженні високих технологій” (О.Глобін, 2015:47), що обумовлює актуальність проблеми вибору змісту математичної освіти основної школи. Дослідники вважають, що компетентнісна орієнтація змісту математики забезпечує реалізацію нових освітніх рефрорм України. 
Серія: Педагогічні науки. - Вип.3. - Бердянськ : БДПУ, 2019. - 453 с.

Головне при цьому, на думку Н. Тарасенкової, щоб "компетенізація освіти" не перетворилася на заміну "термінів ЗУН на термін “компетентність” (Н.Тарасенкова, 2017:16).

М. Бурдою досліджено питання компетентнісної орієнтації змісту шкільних підручників з математики та загальні вимоги до відбору змісту підручника геометрії профільного рівня 3 урахуванням предметних, надпредметних геометричних та ключових компетентностей (Бурда, 2014, 2015). Д. Васильєва розглядає аксіологічний потенціал шкільних підручників алгебри і початку аналізу згідно засад компетентнісного підходу та акцентує увагу на включення в їх зміст аксіологічного спрямування завдань (Д. Васильєва, 2015). Цікавим є дослідження змісту та структури підручників різних країн. Аналізуючи зміст сучасних підручників Ізраїлю, Молдови та Індії, Д. Васильєва зазначає, що "провідною тенденцією створення навчальної книги” у світі “ $є$ забезпечення освітніх потреб учнів і фрормування ключових і предметних компетентностей” (Д. Васильєва, 2018 : 84). Дослідниця висловлює думку про можливість використання різноманітних задач у процесі навчання математики в Україні для формування компетентностей учнів. У цьому аспекті варто сказати, що питання включення завдань компетентнісно орієнтованого змісту розглядається багатьма дослідниками. Зокрема, Ю. Хворостіна, А. Підопригора визначають розвиток математичних компетентностей при розв'язуванні текстових задач (Ю. Хворостіна, А. Підопригора, 2018). М. Афанасьєва також акцентує увагу на провідній ролі математичних задач у формуванні математичної компетентності учнів.

3 урахуванням значного внеску вітчизняних вчених, методистів у дослідження цієї проблеми та розробку сучасних освітніх програм 3 математики на компетентнісній основі важливим $€$ питання фрормування компетентнісного змісту сучасних підручників математики з включенням компетентнісно орієнтованих завдань. Так, у інструктивно-методичних матеріалах для проведення експертами експертиз електронних версій проектів підручників (Наказ, 2018) визначено, що "важливу роль у реалізації компетентнісного навчання мають відігравати завдання, спрямовані на пояснення фрактів, процесів, явищ, виявлення причиново-наслідкових зв'язків, відкриття нових знань або способів дій, розв'язання проблем практичного характеру тощо" (Наказ МОН від 31.10.2018 № 1183, 2018 : 8). Акцентується увага на доцільності того, щоб такі завдання "будувалися на матеріалі не лише одного предмета, а були комплексними, передбачали залучення знань з інших предметів". У зв'язку з цим є підстави вважати, що формування компетентнісно орієнтованого змісту сучасного підручника математики в багатьох аспектах спирається на міжпредметні зв'язки математики 3 іншими навчальними предметами. Відомо, що міжпредметні зв'язки забезпечуються координацією та інтеграцією знань та вмінь учнів з різних дисциплін. Отже, метою статті $є$ аналіз сучасних підручників математики щодо реалізації міжпредметних зв'язків математики та інформатики в компетентнісно орієнтованому змісті сучасного підручника математики.

Методи та методики дослідження. Сформульована мета досягається завдяки аналізу статей, наукових праць, що стосуються 
теорії та практики шкільної навчальної літератури, розробки змісту сучасного підручника математики на засадах компетентнісного підходу для систематизації та узагальнення основних факторів впливу, принципів та дидактичних умов формування компетентнісно орієнтованого змісту сучасного підручника математики; аналізу змісту сучасних підручників математики на наявність задач, які реалізують міжпредметні зв'язки математики та інформатики; узагальненню щодо шляхів реалізації міжпредметних зв'язків математики та інформатики.

Результати та дискусії. Аналіз теорії та практики формування змісту шкільної навчальної літератури дозволив визначити, що чинниками, які впливають на стан навчальної літератури у певний історичний період, є: “державна політика у галузі освіти; розвиток науки, техніки та культури; зміст та структура середньої освіти; принципи і методи навчання; науковометодичне забезпечення навчальної літератури" (О. Жосан, 2013: 12). Причому, ці чинники не тільки впливають на стан шкільної навчальної літератури, а і є взаємопов'язаними та взаємообумовлюють один одного. Слід зазначити, що стан шкільної навчальної літератури як педагогічного, соціального та книгознавчого явища безпосередньо впливає на зміст, структуру та формат шкільної навчальної літератури. Крім того, будь-яка шкільна навчальна література має виконувати ряд функцій задля досягнення освітньої мети (О Жосан, 2013: 11).

Згідно зі вищесказаним, визначаємо, що на формування змісту сучасного підручника математики впливають: провідні засади освітньої реформи (Концепція “Нова українська школа”) (2016); загальна інформатизація суспільства; потреба в освічених, творчих, креативних громадянах та конкурентоспроможних фахівцях, здатних до самовдосконалення та самореалізації тощо. М. Бурда та інші вчені, досліджуючи питання реалізації компетентнісного підходу в навчанні математики, виділяють декілька факторів, які впливають на формування компетентнісно-орієнтованого змісту математичної освіти (О.Глобін, 2015:49-51):

1. Значення математичної освіти для життєдіяльності особистості. Вибір цього фактора дослідники пояснюють тим, що зміст та обсяг математичного матеріалу впливає на якість математичної підготовки молодого покоління, правильне їх уявлення про природу математики, її значення в загальному розвитку особистості та успішне вивчення учнями інших дисциплін, у тому числі природничого характеру.

2. Урахування соціальних потреб суспільства і цілей, які воно ставить перед навчанням математики. Цей фактор визначається дослідниками як пріоритетний у формуванні компетентнісно-орієнтованого змісту математики, тому що соціально-економічні та науково-технічні тенденції розвитку суспільства суттєво впливають на вибір цілей навчання, які виступають основним критерієм змісту навчального матеріалу;

3. Системний підхід до відображення компонентів математичної науки в шкільних підручниках та психолого-дидактичне обґрунтування цього відображення. У зв'язку з цим фактором дослідники акцентують увагу на необхідності вивчення того, як відображаються в математиці різні види 
діяльності та враховуються тенденції розвитку математичної науки.

4. Урахування основних видів діяльності людини, структури і їх особливостей. Цей фактор вчені визначають як важливий у формуванні сучасного змісту математичної освіти основної школи, вбачаючи його реалізацію в ґрунтовному психолого-педагогічному аналізі основних видів діяльності суспільства, що пов'язані 3 математичною наукою (виробництво, сімейний побут, управління тощо).

5. Урахування змін у галузі техніки, виробництва, освіти, комунікацій. Дослідники вважають, що ці зміни спонукають до переосмислення традиційного змісту математики з урахуванням сучасних тенденцій науковотехнічного прогресу.

6. Профрільне навчання в старшій школі. Визначається, що саме профільне спрямування старшої школи впливає на формування змісту математичної освіти основної школи. У зв'язку з цим учені акцентують увагу на важливості організації допрофрільного навчання в основній школі та врахування його принципів при формуванні змісту навчання.

Фактори, які впливають на формування змісту навчання математики, впливають на принципи відбору цього змісту та засоби їх реалізації. До принципів відбору відносять (О.Глобін, 2015: 51-70):

1. Принцип соціальної ефективності навчання, який передбачає реалізацію основних функцій математичної освіти. До функцій автори відносять: власне математичну освіту, яка має забезпечувати високий рівень математичної підготовки учнів як майбутнього наукового потенціалу держави; освіта за допомогою математики, яка забезпечує готовність учнів до застосування математичного апарату для розв'язування проблем навколишньої дійсності; спеціальна математична освіта як елемент допрофільної підготовки учнів, яка має забезпечити свідомий вибір учнями майбутньої профрільної орієнтації. Разом з тим, автори зазначають, що в сучасних підручниках переважає зміст, який реалізує більше першу функцію математичної освіти, хоча з урахуванням швидких темпів розвитку нашого суспільства необхідно приділяти більше уваги другій функції математичної освіти. Ми підтримуємо цю думку, але вважаємо, що при виборі змісту навчального математичного матеріалу необхідно враховувати і допрофрільний аспект математичної освіти. Тому що здатність учня до застосування математичного апарату до вирішення проблем реального світу та вмотивований вибір майбутньої професії $\epsilon$ запорукою ефективного фрормування компетентного випускника закладів загальної середньої освіти, готового до майбутньої самореалізації.

2. Принцип відповідності: врахування структури та рівнів навчальної математичної діяльності учнів, тобто зміст навчання (загальноосвітній, поглиблений), визначається типом мислення (переважно емпіричний або теоретичний), що реалізується через певну навчальну діяльність, де переважають емпіричні або теоретичні узагальнення. Саме від виду узагальнення в освітній діяльності, як вважають учені, і залежить вибір змісту математичного матеріалу. Так, навчальна діяльність де переважає емпіричне узагальнення, визначає вибір змісту навчального матеріалу для 
загальноосвітнього курсу математики, а теоретичне узагальнення - для поглибленого вивчення математики. Також принцип відповідності реалізується через урахування не лише специфіки одиничного, особливого та загального понять, але й видів зв'язку між ними. Навчальні тексти мають відповідати таким етапам пізнання: “від одиничного через особливе до загального і від нього, через логічне обґрунтування, до практики” (О.Глобін, 2015: 53). На думку науковців, принцип відповідності повинен забезпечувати соціальну ефективність змісту математичної освіти. Ми згодні і вважаємо, що при відборі змісту шкільних підручників математики треба більше уваги приділяти прикладній та профільній спрямованості навчального матеріалу.

3. Принципи науковості та прикладної реалізованості. На думку авторів, прикладна спрямованість математики повинна реалізовуватися через правильне розкриття змісту математичного поняття, виділення ситуацій та явищ ,для опису яких це поняття використовується; включення до змісту шкільного курсу математики елементів дискретної математики, що допоможе учням більш ефективно засвоювати курс інформатики та посилити прикладну спрямованість математики. Також вчені акцентують увагу на тому, що компетентнісно-орієнтований зміст математики повинен розкривати гносеологічне їі значення і сприяти ознайомленню учнів 3 методами наукового пізнання реального світу.

4. Принцип діяльнісного спрямування змісту передбачає відбір змісту математичної освіти з урахуванням діяльнісної спрямованості. За допомогою математичного змісту необхідно залучати учнів до активної діяльності, показувати практичну спрямованість математичних понять та фактів. Дослідники наголошують на тому, що зміст повинен сприяти інтенсифікації процесу навчання; засвоєнню знань та формуванню вмінь застосовувати їх на практиці; опануванню способів міркування, які застосовуються в математиці; стимулювати самостійні відкриття математичних фактів та явищ тощо.

5. Принцип пріоритету розвивальної функції навчання: розвиток учнів за рахунок персоніфікованого викладу математики, виокремлення емоційно-ціннісного, художньо-естетичного та творчого потенціалу математики з використанням історико-математичного матеріалу.

6. Принцип наступності передбачає розробку цілісної концепції навчання математики, починаючи з початкової школи. За твердженнями вчених, вона повинна представляти "нову методичну систему навчання ...”, яка “дасть цілісне уявлення про зміст освіти, що відповідає новій соціальній ситуації” (О.Глобін, 2015: 61).

7. Принцип диференційованої реалізованості, який передбачає диференціацію за змістом навчального матеріалу та за рівнями програмних вимог до математичної підготовки учнів основної школи.

8. Модульний принцип відбору змісту навчання передбачає побудову курсу математики з двох части - інваріативної та варіативної.

9. Принцип фрузіонізму: якісна інтеграція змісту геометричного та алгебраїчного матеріалу за рахунок уведення узагальнювальних понять сучасної математики. 
Серія: Педагогічні науки. - Вип.3. - Бердянськ : БДПУ, 2019. - 453 с.

10. Принцип концентризму: зміст шкільного підручника математики повинен бути побудований таким чином, щоб усі компоненти змісту уточнювалися, поглиблювалися та узагальнювалися протягом усього терміну навчання.

О. Глобін, Д. Васильєва та інші до дидактичних умов організації процесу навчання математики в основній школі на засадах компетентнісного підходу відносять: використання відкритих та закритих навчальних завдань; завдань 3 надлишковою та/або недостатньою інформацією; практикоорієнтованих ситуації (Глобін, 2015:30). Вважаємо, що до цього переліку необхідно додати завдання, які будуть безпосередньо сприяти формуванню загальних та ключових компетентностей, інтегрувати знання та вміння 3 інших навчальних предметів.

Відповідно до цього наведемо приклад з результатів нашого дослідження засобів та шляхів реалізації міжпредметних зв'язків математики та інформатики. Теоретико-методологічний аналіз показав, що систематичне використання у процесі навчання математики завдань, які потребують застосування учнями знань та вмінь, набутих на уроках інформатики, забезпечують реалізацію міжпредметних зв'язків математики та інформатики. Такі завдання ми називаємо комп'ютерно-орієнтованими це завдання з математики (задачі, вправи, інтегровані проекти тощо), які потребують від учнів використання інформаційно-комунікаційних технологій та застосування набутих ними знань та вмінь з інформатики.

Також було здійснено узагальнювальний аналіз змісту сучасних підручників математики, алгебри та геометрії, що рекомендовані Міністерством освіти і науки України для використання в основній школі у 2019-2020н.р., на вміст комп'ютерно-орієнтованих завдань. Він показав, що зміст сучасних підручників не в повній мірі відображає міжпредметні зв'язки математики та інформатики, тому що тільки у 3\% від загальної їх кількості (47 підручників) наведені завдання, для виконання яких учням необхідно застосувати знання та вміння з математики та інформатики. Так у підручнику 3 математики для 6 класу за авторством А. Мерзляка, В. Полонського, М. Якіра (2017) виділена окрема рубрика “Дружимо з комп'ютером" та включені завдання, які можна виконувати за допомогою комп'ютера. На жаль, у новому підручнику з математики для п'ятого класу зазначених авторів цього немає (А. Мерзляк та інші, 2018). У підручнику з геометрії для сьомого класу (Г. Бевз, В. Бевз, Н. Владімірова, 2015) включено розробка інтегрованих проектів, де пропонується використання комп'ютера.

Аналізуючи наведений перелік комп'ютерно-орієнтованих завдань у підручниках математики, алгебри та геометрії основної школи, ми прийшли до висновків, що перед учителем математики постає ряд проблем, які він повинен вирішити. Перш за все, він має уявляти ті знання та вміння з інформатики, які сформують учні певного класу відповідно до навчальних програм з інформатики та розв'язувати математичні задачі з використанням IKT. Також учитель повинен вміти оптимально розподіляти час на уроці для розв'язування задач різного типу та виконання комп'ютерно-орієнтованих завдань. Не менш 
важливою проблемою $є$ наявність відповідного обладнання в класі. Тому найчастіше виконання комп'ютерно-орієнтованих завдань задається учням додому або як додаткові для розв'язування на канікулах.

У зв'язку з вищесказаним, вважаємо, що одним зі шляхів вирішення проблеми реалізації міжпредметних зв'язків математики та інформатики $є$ відповідна фрахова підготовка учителів математики під час навчання в педагогічному 3ВО або на курсах підвищення кваліфікації з метою фрормування в них відповідних компетентностей. Разом з цим упровадження в освітній процес факультативних курсі або курсів за вибором, які сприятимуть реалізації міжпредметних зв'язків математики та інформатики, можуть вирішити проблему оптимального розподілу навчального часу на уроці математики та наявності відповідного обладнання. Тим паче, аналіз рекомендованих МОН України програм з математики для допрофрільної підготовки та профрільного навчання показав відсутність розроблених фракультативів або спецкурсів для основної школи, які б забезпечували реалізацію міжпредметних зв'язків математики та інформатики. Треба відмітити, що фрормування змісту такого курсу повинно здійснюватися на основі інтеграції та координації знань та вмінь учнів з обох навчальних предметів.

Висновки. Отже, $є$ всі підстави зробити висновок, що компетентнісно орієнтований зміст сучасних підручників математики може формуватися відповідно до принципів та дидактичних умов, які передбачають включення завдань, які реалізують міжпредметні зв'язки математики та інших предметів. Проведений аналіз показав, що лише в декількох сучасних підручниках 3 математики включено комп'ютерно-орієнтовані завдання, які потребують від учнів застосування знань та умінь, набутих на уроках інформатики. Перспективним видається дослідження питання фахової підготовки майбутніх учителів математики щодо реалізації міжпредметних зв'язків математики та інформатики, а також розробка системи комп'ютерноорієнтованих завдань з математики для учнів основної школи.

\section{Література}

1. Астаф'єва М.М. Роль задач у формуванні математичної компетентності школярів / М. Астафр'єва // Фізико-математична освіта. - 2018. - Випуск 3(17). - С. 20-25.

2.Бевз Г.П. Геометрія : Підруч. для 7 кл. загальноосвіт. навч. закл. / Г. Бевз, В. Бевз, Н. Владімірова. - К. : Видавництво «Відродження», 2015. - 192 с.

3.Бурда М.І. Компетентнісна орієнтація змісту шкільних підручників 3 математики / М. І. Бурда // Проблеми сучасного підручника : зб. наук. праць. - К. : Педагогічна думка, 2014. - Вип. 14. - С. 78-85.

4.Бурда М.І. Підручник з геометрії для профрільного рівня: яким йому бути / М. Бурда // Проблеми сучасного підручника : зб. наук. праць / [ред. кол. ; голов. ред. - О. М. Топузов]. - К. : Педагогічна думка, 2015. - Вип. 15. - Ч. 1. - 55-63 с.

5.Васильєва Д.В. Аксіологічний потенціал підручників з математики для старшої школи / Д. Васильєва // Проблеми сучасного підручника : зб. наук. праць / [ред. кол. ; голов. ред. - О. М. Топузов]. - К. : Педагогічна думка, 2015. - Вип. 15. -Ч. 1. - 700-79 с.

6.Васильєва. Д. Математичні задачі як засіб формування ключових компетентностей учнів / Д. Васильєва // Проблеми сучасного підручника: зб. наук. праць / [за ред. О. М. Топузова]. - К.: Пед. думка, 2018. - Вип. 21. - С. 83-91. 
7.Жосан О.Е. Тенденції розвитку шкільної навчальної літератури в Україні (20-ті - 80-ті роки XX ст..) : [монографія] / О.Е. Жосан. - Кіровоград : Ексклюзивсистем, 2013. - 656 с.

8.Компетентнісний підхід у сучасній освіті : Світовий досвід та українські перспективи / за заг. ред. О. В. Овчарук. - К. : К.І.С., 2004. - 112 с.

9.Компетентнісно орієнтована методика навчання математики в основній школі: Метод. посібник / О.І.Глобін, М.І. Бурда, Д.В. Васильєва, В.В. Волошена, О.П. Вашуленко, Н.Д. Мацько, Т.М. Хмара. —К.: Педагогічна думка, 2015. -245с.

10. Концепція «Нової української школи». - [Електронний ресурс] - Режим доступу : http://mon.gov.ua/Новини\%202016/12/05/konczepcziya.pdf (звернення 07.09.2019 p.).

11. Мерзляк А.Г. Математика : підруч. для 6 кл. загальноосвіт. навч. закладів / А.Г. Мерзляк, В.В. Полонський, М.С. Якір. - Х. : Гімназія, 2017 - 400 с.

12. Мерзляк А.Г. Математика 5 клас : підруч. для закладів загальної середньої освіти / А.Г. Мерзляк, В.В. Полонський, М.С. Якір. -Вид. 2-ге, доопрац. відповідно до чинної навч. програми. - Х. : Гімназія, $2018-272$ с.

13. Наказ МОН від 31.10.2018 № 1183 “Про затвердження Інструктивнометодичних матеріалів для проведення експертами експертиз електронних версій проектів підручників" [Електронний ресурс].- Режим доступу: https://imzo.gov.ua/2018/11/03/ nakaz-mon-vid-31-10-2018-1183-zatverdzhenniainstruktyvno-metodychnykh-materialivdlia-provedennia-ekspertamy-ekspertyzelektronnykh-versi-proektiv-pidruchnykiv/ (дата звернення 7 вересня 2019 р.)

14. Переліки навчальної літератури, рекомендованої Міністерством освіти і науки України для використання у закладах освіти у 2019/2020 навчальному році, Лист МOH від 10.06.2019 № 1/9-365[Електронний ресурс].- Режим доступу: https://imzo.gov.ua/pidruchniki/pereliki/ (дата звернення 7 вересня 2019 р.).

15. Проблеми українського підручникотворення та шляхи їхнього вирішення // «Освітня політика» [Електронний ресурс].- Режим доступу : http://educationua.org/ua/component/content/article/11-podij/1326-problemi-ukrajinskogo-pidruchnikotvorennyata-shlyakhi-jikhnogo-virishennya (дата звернення 7 вересня 2019 р.).

16. Прус А.В. Про компетентнісний підхід у навчанні математики в класах суспільно-гуманітарного напряму / А. В. Прус // Педагогічний дискурс. - 2013. Вип. 14. - С. 372-376.

17. Раков С.А. Математична освіта: компетентнісний підхід з використанням IКТ : [моногр.] / С.А. Раков. - Х. : Факт, 2005. - 360 с. Бурда М. І.

18. Савченко О. Я. Уміння вчитися як ключова компетентність загальної середньої освіти / О.Я. Савченко // Компетентнісний підхід у сучасній освіті : світовий досвід та українські перспективи. Бібліотека з освітньої політики / за заг. ред. О. В. Овчарук. - К. : К.І.С., 2004. - С. 34-52.

19. Селевко Г. Компетентности и их классификация / Г. Селевко // Народное образование. - 2004. - № 4. - С. 138-143.

20. Тарасенкова Н.А. Компетенізація математичної освіти: сутність та етапи реалізації / Н. Тарасенкова // Матеріали міжнародної науково-методичної конференції «Проблеми математичної освіти» (ПМО - 2017), м. Черкаси, 26-28 жовтня 2017 р. - Черкаси: ФОП Гордиенко, 2017. - С. 16-18.

21. Хворостіна Ю.В. Розвиток математичних компетентностей при розв'язуванні текстових задач / Ю. В. Хворостіна, А. В. Підопригора // ФМО. - 2018. - №3 (17). - Режим доступу : https://cyberleninka.ru/article/n/rozvitok-matematichnihkompetentnostey-pri-rozv-yazuvanni-tekstovih-zadach (дата звернення 7 вересня 2019 р.).

22. Часнікова О. Компетентнісний підхід в освіті як основа її реформування / О. Часнікова // Народна освіта. - 2014. - Випуск№3(24) - Режим доступу : https://www.narodnaosvita.kiev.ua/?page_id=2607 (дата звернення 7 вересня 2019 р.). 


\section{References}

1.Astafieva, M. (2018). Rol zadach u formuvanni matematychnoi kompetentnosti shkoliariv [The role of task in the formation of mathematical competence of students], Fizyko-matematychna osvita, Vypusk 3(17), 20-25 [in Ukrainian].

2.Bevz, H. (2015) Heometriia : Pidruch. dlia 7 kl. zahalnoosvit. navch. zakl. [Geometry]. Kyiv : Vydavnytstvo «Vidrodzhennia».

3. Burda, M. (2014). Kompetentnisna oriientatsiia zmistu shkilnykh pidruchnykiv z matematyky [Competency-based orientation of school textbooks in mathematics], Problemy suchasnoho pidruchnyka : zb. nauk. prats., K. : Pedahohichna dumka, Vyp. 14., 78-85.

4.Burda, M. (2015). Pidruchnyk z heometrii dlia profilnoho rivnia: yakym yomu buty [Textbook on geometry for profile level: what will it be], Problemy suchasnoho pidruchnyka : zb. nauk., K. : Pedahohichna dumka, Vyp. 15., Ch. 1., 55-63.

5. Vasylieva D. (2015). Aksiolohichnyi potentsial pidruchnykiv z matematyky dlia starshoi shkoly [Axiological potential of mathematics textbooks for high school], Problemy suchasnoho pidruchnyka : zb. nauk. Prats, K. : Pedahohichna dumka, Vyp. 15., Ch. 1., 700-79.

6. Vasylieva, D. (2018). Matematychni zadachi yak zasib formuvannia kliuchovykh kompetentnostei uchniv [Math tasks as means of formation of key competences of students], Problemy suchasnoho pidruchnyka: zb. nauk. Prats, K.: Ped. dumka, Vyp. 21., 83-91.

7.Zhosan, O. (2013). Tendentsii rozvytku shkilnoi navchalnoi literatury v Ukraini (20-ti - 80-ti roky KhKh stolittia) [Trends in the development of school literature (20th 80th years of XX century)]. Kirovohrad : Ekskliuzyv-system, 2013. - $656 \mathrm{~s}$.

8.Ovcharuk, O. (2004). Kompetentnisnyi pidkhid u suchasnii osviti : Svitovyi dosvid ta ukrainski perspektyvy [Competence approach in modern education : World experience and Ukrainian prospects]. K. : K.I.S.

9.Hlobin O., Burda M., Vasylieva, D., Voloshena, V., Vashulenko, O., Matsko, N., Khmara, T. (2015). Kompetentnisno oriientovana metodyka navchannia matematyky $v$ osnovnii shkoli: Metod. posibnyk [The competence oriented methods of teaching mathematics in the primary school]. K.: Pedahohichna dumka, 2015.

10. Kontseptsiia «Novoi ukrainskoi shkoly» (2016) [The concept of "New Ukrainian schools"]. Retrieved from: http://mon.gov.ua/Novyny\%202016/12/05/konczepcziya.pdf/

11. Merzliak, A., Polonskyi, V., Yakir, M. (2017). Matematyka : pidruch. dlia 6 kl. zahalnoosvit. navch. zakladiv [Math grade 6]. Kh. : Himnaziia.

12. Merzliak A.H., Polonskyi V., Yakir M. (2018). Matematyka 5 klas : pidruch. dlia zakladiv zahalnoi serednoi osvity [Math grade 5]. Kh. : Himnaziia.

13. Nakaz MON vid 31.10.2018 №1183 "Pro zatverdzhennia Instruktyvnometodychnykh materialiv dlia provedennia ekspertamy ekspertyz elektronnykh versii proektiv pidruchnykiv" [About approval of methodical materials for carrying out examinations by experts of electronic versions of textbooks projects].Retrieved from:: https://imzo.gov.ua/2018/11/03/ nakaz-mon-vid 31-10-2018-1183-zatverdzhennia-instruktyvno-metodychnykh-materialivdliaprovedennia-ekspertamy-ekspertyz-elektronnykh-versi-proektiv-pidruchnykiv/

14. Pereliky navchalnoi literatury, rekomendovanoi Ministerstvom osvity i nauky Ukrainy dlia vykorystannia u zakladakh osvity u 2019/2020 navchalnomu rotsi, Lyst MON vid 10.06.2019 № 1/9-365 [The lists of textbooks recommended by the Ministry of education and science of Ukraine for use in educational institutions in the 2019/2020 academic year]. Retrieved from: https://imzo.gov.ua/pidruchniki/pereliki/

15. Osvitnia polityka (2019). Problemy ukrainskoho pidruchnykotvorennia ta shliakhy yikhnoho vyrishennia [The problems of Ukrainian textbooks and their solutions]. Retrieved from: http://education-ua.org/ua/component/content/article/11-podiji/1326-problemiukrajinskogo-pidruchnikotvorennya-ta-shlyakhi-ikhnogo-virishennya

16. Prus, A. (2013). Pro kompetentnisnyi pidkhid u navchanni matematyky $v$ klasakh suspilno-humanitarnoho napriamu [On the competence approach in teaching mathematics in the classrooms of the Humanities]. Pedahohichnyi dyskurs, Vyp. 14., 372-376. 
Серія: Педагогічні науки. - Вип.3. - Бердянськ : БДПУ, 2019. - 453 с.

17. Rakov S. (2005). Matematychna osvita: kompetentnisnyi pidkhid z vykorystanniam IKT [Mathematics education: a competency approach with the use of ICT]. Kh. : Fakt, 2005.

18. Savchenko, O. (2004) Kompetentnisnyi pidkhid u suchasnii osviti : svitovyi dosvid ta ukrainski perspektyvy. Biblioteka z osvitnoi polityky [The ability to learn as a key competence of General secondary education], pp.34-52. In O. Savchenko, (Ed). K. : K.I.S.

19. Selevko, H. (2004). Kompetentnosty y ykh klassyfykatsyia [Competence and their classification], Narodnoe obrazovanye, № 4., 138-143.

20. Tarasenkova, N. (2017, 26-28 zhovtnia). Kompetenizatsiia matematychnoi osvity: sutnist ta etapy realizatsii [Competence mathematics education: the nature and stages of implementation], Materialy mizhnarodnoi naukovo-metodychnoi konferentsii «Problemy matematychnoi osvity» (PMO - 2017), Cherkasy: FOP Hordyenko, 16-18.

21. Khvorostina, Yu., Pidopryhora A. (2018). Rozvytok matematychnykh kompetentnostei pry rozviazuvanni tekstovykh zadach [The development of mathematical competence in solving word problems]. FMO, №3 (17). Retrieved from:: https://cyberleninka.ru/article/n/rozvitok-matematichnihkompetentnostey-pri-rozv-yazuvanni-tekstovih-zadach

22. Chasnikova, O. (2014). Kompetentnisnyi pidkhid $v$ osviti yak osnova yii reformuvannia [Competence approach in education as a basis for reform]. Narodna osvita, VypuskNo3(24). Retrieved from: https://www.narodnaosvita.kiev.ua/?page id=2607

\section{АНОТАЦІЯ}

У статті розәлядається наявність міжпредметних зв'язків математики та інсрорматики у компетентнісно орієнтованому змісті сучасних підручників математики. Автором висувається припущення, що формування компетентнісно орієнтованого змісту сучасного підручника математики в багатьох аспектах спирається на міжпредметні зв'язки математики з іншими навчальними предметами. Основними методами дослідження $\epsilon$ теоретико-методологічний аналіз щодо теорії та практики шкільної навчальної літератури, розробки змісту сучасного підручника математики на засадах компетентнісного підходу; аналіз змісту сучасних підручників математики на включення задач, які реалізують міжпредметні зв'язки математики та інформатики; узагальнення иляхів реалізації міжпредметних зв'язків математики та інфрорматики.

У результаті дослідження визначено, що на фрормування змісту сучасного підручника математики впливають провідні засади освітньої реформи (Концепиія "Нова українська школа") (2016); загальна інформатизація суспільства; підвищення рівня національної самосвідомості в Україні; потреба в освічених, креативних громадянах України та конкурентоспроможних фрахівиях, здатних до самопізнання, самовдосконалення та самореалізації тощо. З'ясовано, що компетентнісно орієнтований зміст сучасних підручників математики може формуватися під випливом багатьох фракторів та відповідно до принципів і дидактичних умов, які передбачають включення завдань, які реалізують міжпредметні зв'язки математики та інших предметів. Проведений аналіз показав, що лише в декількох сучасних підручниках $з$ математики включено комп'ютерно-орієнтовані завдання, які потребують від учнів застосування знань та умінь, набутих на уроках інформатики. Перспективними видаються дослідження фрахової підготовки майбутніх учителів математики щодо реалізації міжпредметних зв'язків математики та інфрорматики, а також розробка системи комп'ютерно-орієнтованих завдань з математики для учнів основної школи.

Ключові слова: підручник математики, компетентністний підхід, міжпредметні зв'язки, математична освіта, інфрормаційно-цифрова компетентність. 